\title{
Small Mammal Abundance and Diversity in Forests With and Without Canada Yew, Taxus canadensis
}

\author{
JerRold L. BelAnt ${ }^{1}$ and SteVe K. Windels ${ }^{2}$ \\ ${ }^{1}$ National Park Service, Pictured Rocks Science Center, Box 40, Munising, Michigan 49862 USA \\ ${ }^{2}$ Michigan Technological University, School of Forestry and Wood Products, 1400 Townsend Drive, Houghton, Michigan \\ 49849 USA
}

Belant, Jerrold L, and Steve K. Windels. 2003. Small mammal abundance and diversity in forests with and without Canada Yew, Taxus canadensis. Canadian Field-Naturalist 117(3): 389-392.

Canada Yew (Taxus canadensis) has been extirpated from much of its former range in northeastern North America possibly due to logging, fire, agriculture, and browsing by White-tailed Deer (Odocoileus virginianus). We compared the relative abundance and species diversity of small mammals in five northern hardwood stands containing Canada Yew to five adjacent stands without Canada Yew in the Upper Peninsula of Michigan, during October-November 2000. Overall, 72 individuals were captured (53 in yew, 19 in non-yew); dominant species were Short-tailed Shrew (Blarina brevicauda), Deer Mouse (Peromyscus maniculatus), and Red-backed Vole (Clethrionomys gapperi). Overall mean ( \pm sd) capture rate (individuals/100 adjusted trap nights) in sites with yew $(5.5 \pm 2.2)$ was greater $(P=0.04)$ than mean capture rate in sites without yew (1.9 \pm 1.0). Three indices of species diversity suggested greater small mammal diversity in stands with Canada Yew understories in northern hardwood forests.

Key Words: Canada Yew, Taxus canadensis,.diversity, Michigan, relative abundance, small mammals.

Canada Yew (Taxus canadensis) is an evergreen shrub native to the mixed conifer-hardwood forest of northeastern North America (Martell 1974). Canada Yew requires shaded and moist habitats (Stachowicz and Allison 1995), and is intolerant of even moderate herbivory (Leopold et al. 1947; Snyder and Janke 1976; Allison 1990) and disturbance (e.g., clearcutting; Beals and Cottam 1960; Stachowicz and Allison 1995). Canada Yew has been extirpated from much of its former range in the United States as a consequence of logging and subsequent fire, clearing of land for agriculture, and increased browsing by White-tailed Deer (Odocoileus virginianus) due to population irruptions (Allison 1990; Stachowicz and Allison 1995).

Little information is available regarding the relationship between Canada Yew and bird and small mammal communities. Because of its former range extent and probable importance to forest structure, loss of Canada Yew may have resulted in changes in vertebrate community structure. For example, Black-throated Blue Warblers (Dendroica caerulescens) frequently nest in Canada Yew when it is available (Bent 1963; Holmes 1994). In addition, Canada Yew arils (fruit) and seeds are reportedly eaten by several species of rodents and birds (Fordham 1967 in Martell 1974; Wilson et al. 1996). The structure of Canada Yew may also provide vertical foraging substrate and cover for several rodent species (Kurta 1995). However, we are unaware of other studies describing the importance of Canada Yew to small mammal communities. Our objective was to compare the relative abundance and diversity of small mammals in northern hardwood forests, with and without a Canada Yew understory.

\section{Study Area}

The study was conducted in the northcentral Upper Peninsula of Michigan on lands administered by Pictured Rocks National Lakeshore and Shelter Bay Forests, Incorporated $\left(46^{\circ} 27^{\prime} \mathrm{N}, 86^{\circ} 33^{\prime} \mathrm{W}\right)$. Total mean annual precipitation was $86 \mathrm{~cm}$, including mean annual snowfall of about $380 \mathrm{~cm}$ (Danz 1998). Temperatures during the study ranged from about -2 to $21^{\circ} \mathrm{C}$. Much of the study area was clearcut in the early 1900s (Frederick et al. 1977), but stands have regenerated to Sugar Maple (Acer saccharum) and American Beech (Fagus grandifolia), which comprised $90 \%$ of the trees in the area (Danz 1998). Canada Yew has been present in the study area for $\geq 50$ years (Danz 1998); mean maximum height of Canada Yew on study sites was about $1 \mathrm{~m}$.

\section{Methods}

Field work was conducted from 31 October to 13 November 2000. Five locations were selected. Each location consisted of a treatment (stand with yew understory) and control (stand without yew understory) site, with paired sites separated by $25-100 \mathrm{~m}$. Yew sites varied from about 0.3-7.0 ha. Twenty-five stations were located at $10 \mathrm{~m}$ intervals in 3-4 lines separated by $10 \mathrm{~m}$. Number of lines and number of stations/line were adapted to individual yew stands. Stations in sites with yew were $\geq 5 \mathrm{~m}$ from the edge of yew cover. Two Victor® mouse snap traps (Woodstream Corporation, Lititz, Pennsylvania, USA) were positioned at each station and baited with a mixture of peanut butter and rolled oats. At each station, traps were separated by $\geq 1 \mathrm{~m}$ and were $\leq 1.5 \mathrm{~m}$ from survey flags. Traps were checked daily and removed after 4 days of trapping 
effort. Thus, each site received 200 unadjusted trap nights of effort. Traps that were sprung with or without capture were adjusted as representing 0.5 trap nights (Belant 1992; Beauvais and Buskirk 1999). All small mammals captured were removed from traps and weighed; traps were rebaited as necessary.

At each trap station, we visually estimated and recorded the percent cover of yew and ferns (Evergreen Woodfern, Dryopteris marginalis) within a 3-m radius of each survey flag. In addition, we recorded the number of tree seedlings ( $<2.5 \mathrm{~cm}$ diameter breast height), yew stems, and percent fern cover within a 1-m quadrat at each survey flag.

We used paired $t$-tests (SAS Institute, Inc. 1990) to compare mean small mammal capture rates (number of individuals $/ 100$ adjusted trap nights) and mean vegetative values in yew and non-yew sites. Means are reported with \pm 1 standard deviation; statistical significance was defined as $P<0.05$.

We used three indices to compare species diversity of small mammals between yew and non-yew stands: Species Richness, Shannon-Weiner $\left(H^{\prime}\right)$, and Simpson's $(\lambda)$ (Colinvaux 1986; Kirkland 1990). Species Richness $(S)$ is a measure of the number of species actually documented by observation or capture. The Shannon-Weiner index $\left(H^{\prime}\right)$ is a measure of the probability of selecting the identity of an individual taken from the sample at random and uses the equation:

$$
H^{\prime}=-\Sigma p_{i} \ln p_{i}
$$

Where $p_{i}$ is the proportion of the total number of individuals in the $i$ th species; $H^{\prime}$ increases with species diversity. Simpson's index $(\lambda)$ is the probability that any two individuals selected at random will be the same species and uses the equation:

$$
\lambda=\Sigma p_{i}^{2}
$$

Simpson's index is actually an inverse measure of diversity in that species diversity increases as $\lambda$ decreases.

\section{Results}

We captured 72 individuals representing five species in 2000 unadjusted trap nights (1000 each in yew and non-yew). Fifty-three individuals were captured in yew sites; 19 individuals were captured in non-yew sites. Mean capture rate/100 ATN was greater $\left(t_{5}=2.94\right.$, $P=0.04)$ in yew sites $(5.5 \pm 2.2$ individuals $)$ than in non-yew sites $(1.9 \pm 1.0$ individuals). The most common species captured in yew sites was Short-tailed Shrew (Blarina brevicauda, 45\%), Deer Mouse (Peromyscus maniculatus, 26\%) and Southern Red-backed Vole (Clethrionomys gapperi, 19\%) (Figure 1). Shorttailed Shrew (42\%) and Deer Mouse (47\%) were the species most frequently captured in non-yew sites. Species diversity of small mammals was greater in stands with Canada Yew, with indices of $S=5, H^{\prime}=1.31$, and $\lambda=0.35$. Species diversity indices in stands without Canada Yew were $S=4, H^{\prime}=1.01$, and $\lambda=0.40$.

Average mean cover of yew in the $3-\mathrm{m}$ radius plots at yew sites was 46 times greater than mean cover of yew in non-yew sites (Table 1). Mean number of yew stems $/ \mathrm{m}^{2}$ in yew sites was significantly greater than mean number of yew stems in non-yew sites. However, the number of Sugar Maple and total tree seedlings was significantly greater in non-yew sites. Percent fern cover in $1 \mathrm{~m}^{2}$ and 3-m radius plots was similar in yew and non-yew sites.

\section{Discussion}

Although the mean number of hardwood seedlings was greater in non-yew stands, increased stem density and percent cover on study sites with Canada Yew provided greater understory structure in northern hardwood forests than did sites without yew. This difference in understory structure was likely responsible for observed differences in small mammal abundance and diversity. Increased structure caused by Canada Yew probably reduces the vulnerability of small mammals to predation through creation of physical barriers or visual obstruction. Several authors have suggested that small mammals use structure to avoid predation (e.g., Nordyke and Buskirk 1991; Kurta 1995).

Seeds of Canada Yew could also provide an important food source for small mammals, and conifer seeds are important food items for many rodent species (Ure and Maser 1982; Gunther et al. 1983). Arils and seeds of Canada Yew are reportedly eaten by Deer Mice (Wilson et al. 1996) which could explain the increased abundance of this species in yew sites. In addition,

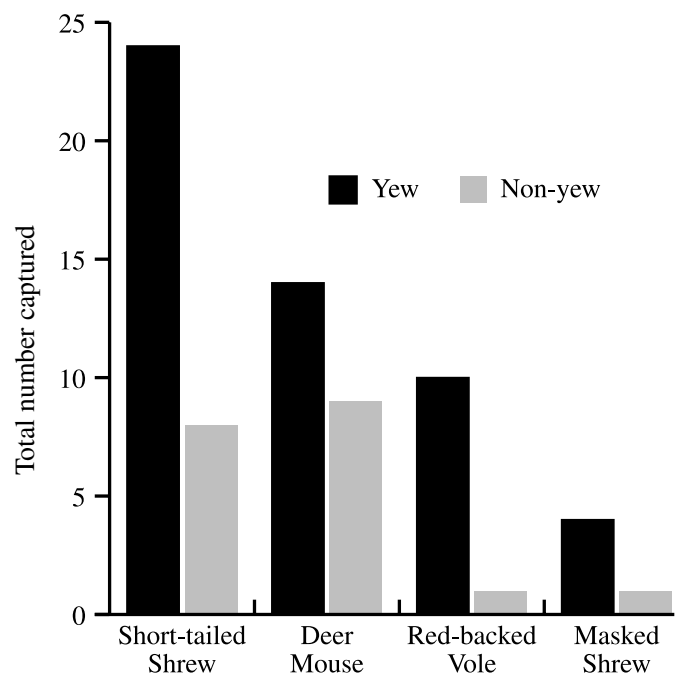

FIGURE 1. Number of individual small mammals captured in northern hardwood stands with and without understories containing Canada Yew $(n=5$ sites/treatment), Upper Peninsula of Michigan, October-November 2000. 
TABLE 1. Vegetative characteristics (mean \pm SD) in northern hardwood stands with and without understories containing Canada Yew ( $n=5$ sites/treatment), Upper Peninsula of Michigan, October-November 2000.

\begin{tabular}{lcccrrr}
\hline & \multicolumn{2}{c}{ Yew } & \multicolumn{3}{c}{ Non-yew } \\
Parameter & Mean & SD & Mean & SD & $t$ & $P$ \\
\hline \% Yew cover in 3-m radius plot & 55.2 & 4.2 & 1.2 & 1.2 & 23.29 & $<0.001$ \\
Number of Yew stems in 1 m² quadrat & 6.7 & 0.4 & 0.1 & 0.1 & 31.53 & $<0.001$ \\
Number of Sugar Maple seedlings & 0.1 & 0.1 & 1.7 & 1.3 & 2.85 & 0.046 \\
Number of American Beech seedlings & 0.3 & 0.2 & 0.6 & 1.1 & 0.85 & 0.848 \\
Number of other seedlings & 0.2 & 0.2 & 0.4 & 0.2 & 0.92 & 0.408 \\
Total number of seedlings & 0.5 & 0.2 & 2.8 & 1.4 & 3.31 & 0.030 \\
\% fern cover in 1 m quadrat $^{2}$ & 5.6 & 2.7 & 4.8 & 0.9 & 0.51 & 0.637 \\
\% fern cover in 3-m radius plot & 7.0 & 1.8 & 7.3 & 1.7 & 0.21 & 0.845 \\
\hline \hline
\end{tabular}

${ }^{1}$ rounding errors account for the 0.1 differences in total mean from sum of individual means.

increased structure and mesic conditions provided by Canada Yew may result in greater invertebrate numbers. Monthey and Soutiere (1985) found higher shrew numbers in logged forests with increased structure at ground level and associated this response to higher invertebrate numbers.

Presence of Canada Yew also affects microclimate by shading which results in increased moisture. Greater abundance of Red-backed Voles in yew sites probably reflects their preference for mesic sites and their comparatively high water requirements (Getz 1968; McManus 1974).

Loss of Canada Yew throughout much of its former range may have affected small mammal and other species abundance and distribution, particularly Redbacked Voles in hardwood forests. If patterns from this study are valid, the greatest effect from loss of yew would be localized reductions in shrew and Redbacked Vole populations. Continued increases in deer populations and human activities (e.g., clearing of land) could exacerbate this effect.

\section{Acknowledgments}

Funding for this study was provided by Pictured Rocks National Lakeshore. We thank Shelter Bay Forests, Incorporated, particularly Marty Wilk, for access to study sites.

\section{Literature Cited}

Allison, T. D. 1990. The influence of deer browsing on the reproductive biology of Canada yew (Taxus canadensis Marsh). I. Direct effect on pollen, ovule, and seed production. Oecologia 83: 523-529.

Beals, E. W., and G. Cottam. 1960. The forest vegetation of the Apostle Islands, Wisconsin. Ecology 41: 743-751.

Beauvais, G. P., and S. W. Buskirk. 1999. Modifying estimates of sampling effort to account for sprung traps. Wildlife Society Bulletin 27: 39-43.

Belant, J. L. 1992. Efficacy of three types of live traps for capturing weasels, Mustela spp. Canadian Field-Naturalist 106: 394-397.

Bent, A. C. 1963. Life histories of North American wood warblers. Part I. Dover Publications, New York, New York. 367 pages.
Colinvaux, P. A. 1986. Ecology. John Wiley and Sons, Inc., New York, New York. 725 pages.

Danz, N. P. 1998. Influence of Canada yew on population structure of sugar maple and beech. M.S. thesis, University of Minnesota, St. Paul, Minnesota. 76 pages.

Fordham, A. J. 1967. Seed dispersal by birds and animals in the Arnold Arboretum (Harvard University). Arnoldia 27: 73-84.

Frederick, D. J., L. Rakestraw, C. R. Eder, and R. A. VanDyke. 1977. Original forest vegetation of Pictured Rocks National Lakeshore and a comparison with present condition. Michigan Academician 9: 433-443.

Getz, L. L. 1968. Influence of water balance and microclimate on the local distribution of the redback vole and white-footed mouse. Ecology 49: 276-286.

Gunther, P. M., B. S. Horn, and G. D. Babb. 1983. Small mammal populations and food selection in relation to timber harvest practices in the western Cascade Mountains. Northwest Science 57: 32-44.

Holmes, R. T. 1994. Black-throated blue warbler (Dendroica caerulescens). The Birds of North America, Number 87. Edited by A. Poole and F. Gill. The Academy of Natural Sciences, Philadelphia and The American Ornithologist's Union, Washington, D.C.

Kirkland, G. L., Jr. 1990. Patterns of initial small mammal community change after clearcutting of temperate North American forests. Oikos 59: 313-320.

Kurta, A. 1995. Mammals of the Great Lakes region. University of Michigan Press, Ann Arbor, Michigan. 376 pages.

Leopold, A., L. K. Sowls, and D. L. Spencer. 1947. A survey of over-populated deer ranges of the United States. Journal of Wildlife Management 11: 163-177.

Martell, D. L. 1974. Canada yew Taxus canadensis Marsh. U. S. Department of Agriculture Forest Service General Technical Report NE-1974: 158-160.

McManus, J. J. 1974. Bioenergetics and water requirements of the redback vole, Clethrionomys gapperi. Journal of Mammalogy 55: 30-44.

Monthey, R. W., and E. C. Soutiere. 1985. Responses of small mammals to forest harvesting in northern Maine. Canadian Field-Naturalist 99: 13-18.

Nordyke, K. A., and S. W. Buskirk. 1991. Southern redbacked vole, Clethrionomys gapperi, populations in relation to stand succession and old-growth character in the central Rocky Mountains. Canadian Field-Naturalist 105: 330-334. 
SAS Institute, Inc. 1990. SAS/STAT User's Guide, Version 6. Fourth Edition. Cary, North Carolina. 1685 pages.

Snyder, J. D., and R. A. Janke. 1976. Impact of moose browsing on boreal-type forests of Isle Royale National Park. American Midland Naturalist 95: 89-92.

Stachowicz, J. J., and T. D. Allison. 1995. Vegetation, browsing, and site factors as determinants of Canada yew distribution in central New Hampshire. Rhodora 97: 357-374.

Ure, D. C., and C. Maser. 1982. Mycophagy of red-backed voles in Oregon and Washington. Canadian Journal of Zoology 60: 3307-3315.

Wilson, P., M. Buonopane, and T. D. Allison. 1996. Reproductive biology of the monoecious clonal shrub Taxus canadensis. Bulletin of the Torrey Botanical Club 123: 7-15

Received 20 April 2001

Accepted 29 March 2004 